\title{
POLITICAL PARTICIPATION AND VOTER TURNOUT IN NIGERIA'S 2011 ELECTIONS
}

\section{J Shola Omotola E Gbenga Aiyedogbon}

J Shola Omotola is a lecturer in the Department of Political Science and Public Administration, Redeemer's University, Ogun State, Nigeria email: sholaomotola@yahoo.com Gbenga Aiyedogbon is Programme Officer, Governance Renaissance Movement (GRM), Kwara State, Nigeria email: gbemihigh@yahoo.com

\begin{abstract}
This article explores political participation as one of the most important indicators of the democratic quality of elections and a prime criterion for defining democratic citizenship. It places specific emphasis on voter turnout as the most important form of political participation, but also as an important indicator of the state of health of any democracy, old or new, consolidated or in transition, where high voter turnout is usually associated with a healthy democracy. More specifically, the article explores voter turnout in Nigeria's 2011 general elections and the factors underlying the turnout. Following brief theoretical postulations on political participation and the history of voter turnout in Nigeria, the article analyses the turnout in 2011, reflecting on its underlying forces and spatial dimensions. It also covers generally discernible trends and notable variations across geopolitical zones. Overall, the growing deployment and influence of the social media, the electoral reform process, which boosted public trust in electoral institutions and processes, President Jonathan's oft-repeated assurances to the local and international community that he would not interfere in the electoral process, the active engagement of civil society, violence before and during elections, the northsouth divide over the rotational presidency and zoning all had an impact on turnout. The findings have important policy implications for improving turnout in future elections.
\end{abstract}

\section{INTRODUCTION}

Elections have generally been acknowledged as a cardinal pillar of a democratic political system (Bratton 1998; Schedler 2002; Diamond 2008; Lindberg 2009a, 
2009b, 2009c; Omotola 2010a). This is particularly the case where elections satisfy acceptable democratic standards, or, better still, what Lindberg $(2004,2006)$ calls the 'democratic qualities of elections', namely competition, participation and legitimacy. Elections that fall short of these standards can only serve to undermine the consolidation of democracy.

This article focuses on political participation as one of the important indicators of the democratic quality of elections. In addition, political participation is considered a prime criterion for defining democratic citizenship and the role of citizens in the political process (Dalton 2006). However, given that political participation is, in itself, multifaceted, including, among other things, membership of a political party, involvement in political campaigns, contributions to political debates, funding political activities, contesting elections, this article places specific emphasis on voter turnout.

Apart from its qualification as the most important form of political participation, voter turnout has also been seen as an important indicator of the state of health of any democracy, old or new, consolidated or in transition, where a high turnout is usually associated with a healthy democracy and a low one with an unhealthy one (Kuenzi \& Lambright 2007; Freitag 2010). More specifically, the article explores voter turnout in Nigeria's 2011 general elections and the factors underlying it.

Without any doubt, this is a daunting challenge. How do we, for example, measure the level and quality of participation, using voter turnout as the core indicator? Moreover, in a country characterised by a high degree of pluralism, where ethno-regional-cum-ethnic and religious identities often take centre stage in matters of national significance, including presidential elections, in what ways, if any, do such forces of identity influence the spatial distribution of voter turnout?

This is a question that relates to the autonomy of citizens 'in being sufficiently informed about government to exercise a participatory role' (Dalton 2006, p 2) without undue external influence. While the comparative literature suggests some measures, critical questions abound, especially in elections characterised by fraud and violence, where results are frequently contested by opposition parties and, in a few cases, altered or annulled altogether by the election tribunal/ court.

The situation is worse in cases where voter registers, upon which voting and the computation of voter turnout are predicated, are far from accurate. Such incidents were a recurring characteristic of Nigeria's elections between 1999 and 2007 (Omotola 2010a). It is important that we engage with this largely neglected aspect of Nigeria's elections to ascertain the form and character of participation. This is the main focus of this article.

The first section theorises about political participation as a cardinal pillar of 
democracy, focusing on voter turnout as its most crucial indicator. The second historicises the turnout in Nigeria's elections before 2011. This is followed by the analytical fulcrum of the article - voter turnout in the 2011 election. This section also reflects on the spatial dimensions of turnout, accounting for discernible trends generally and notable variations across geopolitical zones. The last substantive section synthesises the findings and reflects on the policy implications for improved political participation in the country.

\section{PARTICIPATION AS A CARDINAL PILLAR OF DEMOCRACY}

Political participation, which has attracted considerable academic interests (Pateman 1970; Nelson 1979, 1976; Booth \& Seligson 1978; Verba \& Nie 1972; Huntington \& Nelson 1976; Conge 1988) is one of the oldest concepts in the comparative study of politics. Yet it remains an essentially contested concept, with a variety of definitions on parade, each of which is either too general or too narrow. Conge (1988) made a comprehensive study of some of these definitions to underscore this limitation, as well as the typology of arguments over the meaning of the concept.

A few examples of such definitions will suffice. Verba \& Nie (1972, pp 2-3) define political participation as behaviour designed to affect the choice of governmental personnel and / or policies. For Kaase \& Marsh (1972, p 42), political participation entails 'all voluntary activities by individual citizens intended to influence either directly or indirectly political choices at various levels of the political system'. In a more expanded version, Nelson $(1979$, p 8$)$ defines political participation as an 'action of private citizens intended to influence the actions or the composition of national or local government'.

In yet another attempt to expand the definition, Booth \& Seligson $(1978, \mathrm{p} 6)$ define political participation as 'behaviour influencing or attempting to influence the distribution of public goods', including security of lives and property and infrastructural and social amenities such as roads, schools, health centres and other services provided by the government.

From these definitions Conge (1988) moved on to identify the broad categories of debate about the meaning of political participation. These were:

- Active versus passive form: should political participation be defined only in terms of action - voting, campaigning for a political party - or should it include passive forms - a feeling of patriotism, an awareness of political issues?

- Aggressive versus non-aggressive behaviour: should a definition of political participation embrace civil disobedience and political violence or should it be limited to more 'conventional' activities? 
- Structural versus non-structural objects: should efforts to change or maintain the form of government be included in a definition of political participation or should the definition be limited to changing or maintaining government authorities and / or their decisions?

- Governmental versus non-governmental aims: should political participation be limited to behaviour directed towards government authorities, policies and/or institutions or should it include phenomena outside the realm of government?

- Mobilised versus voluntary action: should behaviour sponsored and guided by the government to enhance its welfare be called political participation or should the term be confined to behaviour initiated by citizens in pursuit of their interests?

- Intended versus unintended outcomes: should behaviour that has an unintended consequence for a government be defined as political participation?

These are salient but contentious issues that cannot easily be disregarded when discussing political participation. Consequently, and guided by the dual requirements of generality and precision, Conge (1988, p 147) offers what he considers to be a more nuanced definition of political participation that is neither too general nor too narrow: 'individual or collective action at the national or local level that supports or opposes state structures, authorities, and/or decisions regarding allocation of public goods ... the action can be verbal or written ... violent or non-violent ... can be of any intensity'.

Although a useful definition, this does not lay to rest the debate about the constitutive elements of political participation. For example, should such actions be mobilised or voluntary, violent or not, and so on? While the debate will probably remain with us for years to come (and we will not pursue it in this article), some salient points should be noted for their relevance and application to this study.

The first and most basic is the fact that political participation essentially embraces mechanisms through which the public can express their preferences in relation to public affairs. The second, although it is applicable to a broad category of activities, is that elections seem the most basic and salient activity through which allocation of public goods can be influenced. It is in this connection that voting in elections is considered to be the most important form of political participation.

Voter turnout has been identified in the extant literature as one of the core ways of measuring the level of participation in any election (Blais \& Dobrzynska 1998). Voter turnout is usually measured as a percentage of registered voters who vote. The assumption is that the higher the level of voter turnout, the higher the level of participation and, by extension, the greater the democratic quality 
of the election (see Lindberg 2004, 2006; Altman \& Perez-Linan 2002, Lijphart 1997). As Bratton (1999, p 570) bluntly puts it, 'voter registration was revealed as the single most important determinant not only of a citizen's behavior but also of overall participation, outweighing any other institutional, cultural, or social consideration'.

Other major studies support the claim that declining voter turnout is a reflection of the poverty of democracy (Berg-Schlosser \& Kersting 2003; Cornwall 2002; Young 2000). What factors, then, explain the voting behaviour of the electorate, including turnout? Again, the extant literature has shown that voting behaviour is largely a function of institutional, cultural and socio-economic factors (see Budge \& Farlie 1977). For some, the social group theorists, the forces of identity such as class, religion, and urban-rural residency, among others, go a long way to influencing voting behaviour (Driskell, Embry \& Lyon 2008). For instance, individuals with higher levels of education and income (socio-economic status) are more likely to participate than those with lower levels.

For others, party identification is the crucial element. The main assumptions of this theory include the existence of a truly democratic order, where most voters feel a lifetime attachment to a party due to family socialisation, and the more a voter is attached to a party, the more likely he or she is to turn out to vote. The reference to family socialisation simply underscores the argument that early political experiences shape political behaviour (Franklin 2004). As stated elsewhere, 'voting behavior is, in part, a gradually acquired habit' (Plutzer 2002, p 42; Meredith 2009, p 188).

There is also the rational choice theory, which emphasises the effort to maximise political gains. According to this theory, if voters feel their vote may not produce the desired outcome, they may opt not to vote. Here, the core determinants are the issues or party programmes which come closest to the democratic aspirations of the voter. Making an informed decision in such a situation requires that voters have access to adequate and appropriate information.

With reference to voter turnout, theoretical explanations with practical applications have been advanced, which also draw on an institutional paradigm. Some have emphasised the salience of electoral systems, with the proposition that proportional representation results in a higher voter turnout than electoral systems like the simple plurality model (Ladner \& Milner 1999; Milner \& Ladner 2006; Freitag 2010). This assumption has been tested and largely validated. For instance, Milner \& Ladner (2006), in their comprehensive study of turnout in Swiss municipal elections, found a positive relationship between proportional representation elections and voter turnout.

In another fascinating study, on voter turnout in Africa, Kuenzi and Lambright (2007) found that the electoral formula has a significant effect. But 
this is not always the case, as Freitag (2010) found that cultural factors were more important than institutional factors in Swiss sub-national parliamentary elections, which he himself admitted might not be the case at national and international levels.

Another institutional factor that has been identified as a possible influence on voter turnout is the nature of electoral reform. The argument here is that electoral reform that promotes voter confidence in electoral institutions, processes and outcomes can engender a high level of turnout, and vice versa (Omotola 2011a; Schaffer 2002). The turnout will be higher if political parties and candidates are able to take advantage of electoral reforms for effective mobilisation. If not, the reforms may have only a marginal effect on turnout (Stein, Owens and Leighley 2002). There is also a geographical/spatial dimension to the debate. Here, the concern is with distance and accessibility (Gimpel \& Schuknecht 2003; Squire, Wolfinger \& Glass 1987). If voting centres are close and easily accessible there is the likelihood of higher voter turnout, and vice versa.

However, these enabling factors are seldom present, which is why there is increasing talk of declining voter turnout in both developed and developing democracies (see Gray \& Caul 2000). This is not unconnected with a number of factors, notably declining levels of public trust in electoral institutions, which casts doubt on the usefulness of a vote in terms of its power to determine an electoral outcome. The relative weakness and fragmentation that tend to characterise opposition parties, as well as troubling issues of electoral violence and corruption, have also been identified as contributing to declining levels of voter turnout (Lindberg 2009b; Omotola 2011a). Where is Nigeria located within these theoretical expositions?

\section{AN OVERVIEW OF VOTER TURNOUT IN NIGERIA}

The year 1959 represented an important landmark in Nigeria's electoral history. That was the year the first general election was held - on 12 December preparatory to the attainment of political independence in October 1960. A total of 9043404 voters was registered, of whom 7189797 (79.5\%) voted (Kurfi 1983, p 174, quoted in Olaniyi 2008, p 105). This turnout, which can be regarded as impressive, has been explained as a result of 'social and political pressures as well as administrative action by the regional governments and local authorities which exhorted the voters to go to the polls' (Post 1963, quoted in Olaniyi 2008, p 105).

Although the regions took administrative action to promote voter turnout, their efforts yielded different level of success. For instance, while Lagos, then Federal Capital Territory, recorded a $76.2 \%$ turnout, the northern, eastern and 
western regions recorded $89.4 \%, 75.3 \%$ and $71.2 \%$, respectively (Ojiako 1981, p 76).

\section{Table 1}

Voter Turnout in Nigeria, 1959-2007

\begin{tabular}{|l|c|c|c|}
\hline \multicolumn{1}{|c|}{ Elections } & Registered voters & Turnout & Percentage \\
\hline 1959 General election & 9043404 & 7189797 & 79.50 \\
\hline 1979 Presidential election & 48633782 & 16846633 & 34.00 \\
\hline 1979 Senate election & 48633782 & 12532195 & 25.80 \\
\hline 1979 Representatives election & 48633782 & 14941782 & 30.70 \\
\hline 1983 Presidential election & 65304818 & 25430096 & 38.00 \\
\hline 1983 Senate election & 65300000 & $\mathrm{Na}$ & $\mathrm{Na}$ \\
\hline 1983 Representatives election & 65300000 & $\mathrm{Na}$ & $\mathrm{Na}$ \\
\hline 1992 Senate election & 36923571 & 14716074 & 39.00 \\
\hline 1992 Representatives election & 36923571 & 15329670 & 41.00 \\
\hline 1993 Presidential election & 37826460 & 14321963 & 37.00 \\
\hline 1999 Presidential election & 57838945 & 30280052 & 52.30 \\
\hline 1999 Senate election & 57938945 & 24386427 & 42.11 \\
\hline 1999 Representatives election & 57938945 & 23573407 & 40.70 \\
\hline 2003 Presidential election & 60823022 & 42018735 & 69.10 \\
\hline 2003 Senate election & 60823022 & 29995171 & 49.30 \\
\hline 2003 Representatives election & 60823022 & 30386270 & 50.00 \\
\hline 2007 Presidential election & 61567036 & 35397517 & About \\
& & valid votes & 58.00 \\
\hline
\end{tabular}

Source: Compiled by the author from various sources, including: 'Elections in Nigeria', African Elections Database, available at: africanelections.tripod.com/ng.html; 'Presidential Elections, 1999-2011 in Figures', Vanguard, 23 April 2011, available at: www.vanguardngr.com/2011/04/presidential-elections-1999-2011in-figures / ; Olaniyi 2008, p 110; Nwosu 2008, pp 296-298, 326

However, as is evident from Table 1, since the 1959 general election voter turnout has been less impressive for a number of reasons. For example, all stages of the 1979 elections were characterised by low voter turnout, with $34 \%$ of voters voting in the presidential election, $28.8 \%$ in the Senate and $30.7 \%$ in the House of Representative s elections. This was the lowest turnout in Nigeria's elections to date. This development may not be unconnected to the fact that the 1964 general 
election, which was the last before the first military interregnum between 1966 and 1979, was characterised by massive thuggery, violence and boycotts. Indeed, the result was largely inconclusive and contributed to the military coup of 1966 (see Ojiako 1981; Osaghae 1998).

This bad experience may have raised doubts in the minds of many voters about the democratic and developmental qualities of elections generally and their votes in particular. Moreover, the 13 years of military rule also meant that Nigerians had been out of tune with electoral politics over the period, thereby being denied the requisite experience that could have come with regular and periodic elections. In a related argument, Dudley (1982, p 200) underscores the salience of experience in shaping voting behaviour and how the lack of it, given that 1979 was the first time the voting age was lowered to 18, accounted for the low voter turnout.

Although there was a marginal increase in the 1983 elections the turnout was still very low. In the presidential elections, for example, only 25430096 of the 65304818 registered voters cast their votes, which amounts to $38 \%$. On the one hand one may be tempted to attribute the marginal increase in turnout to the experience acquired in the 1979 election, in line with the logic of the argument that experience influences voting behaviour. On the other, it is possible to place critical question marks against the reliability of the data, given that the election was characterised by massive corruption and unprecedented violence, especially in the South Western states of Ondo and Oyo, which played a major role in the eventual collapse of the Second Republic (see Osaghae 1998; Babarinsa 2002; Joseph 1987).

The second coming of the military, on 31 December 1983, lasted longer than expected - until May 1999. The 1992/ 93 and 1999 elections, held during the transition period, occupy important positions in the annals of Nigeria's electoral history. While the former was considered, arguably though, the freest and fairest ever held in the country (Omoruyi 1993; Nwosu 2008), the latter eventually placed Nigeria on the path of democracy after 16 years of uninterrupted military rule.

The turnout for the Senate elections of 1992 was 39\% and for the House of Representatives $41 \%$. For the presidential election of 1993 it was $37 \%$. The low turnout can be explained by the high level of inconsistency and apparently endless transition programme under the Babangida regime (Diamond, Kirk-Green \& Oyediran 1997; Omotola 2008), which tended to reduce the level of public trust in the transition.

In the 1999 elections, however, there was some improvement in turnout, though it was still generally poor $-52.3 \%$ for the presidential election, $42.11 \%$ for the Senate and $40.7 \%$ for the House of Representatives elections. The increase in turnout was partly due to the desperation of Nigerians to get the military out of 
power after years of its misadventures in governance (Omotola 2004). However, the generally low level of turnout can be explained by the perception of the military as an institution incapable of instituting genuine democracy, given, especially, the betrayal of the past in the light of the 12 June 1993 experience. Some have also blamed the alliance between the then Action for Democracy (AD) and the All Nigeria Peoples Party (ANPP) in the presidential election. The argument was that many supporters of these parties who did not subscribe to the idea of the alliance decided to abstain (Olaniyi 2008).

In 2003 the turnout for the presidential election was 69.1\%, for the Senate election $49.3 \%$ and for the House of Representatives election 50\%. These figures seem high when assessed against the background of the undue militarisation of the electoral process, which scared many potential voters away (Ajayi 2006; Omotola 2004). A probable explanation of the high turnout for the presidential election was the fact that it was contested by 20 of the 30 registered political parties. One reason given for the comparatively high turnout is that the electorate had confidence in the electoral body that conducted the election and that many voters wanted to associate with the ruling party (Olaniyi 2008, p 109). Another plausible explanation may be that this was a second election, which many consider central to the process of consolidation (see, eg, Bratton 1998). Yet, the election was administered by a civil regime, unlike the 1999 transitional election, which was held under a military regime.

The 2007 election has generally been considered to be the worst in Nigeria's electoral history (Omotola 2009; 2010a; 2007; Adebayo \& Omotola 2007; Suberu 2007; JAE 2007; Odion-Akhaine 2009). A total of 35397517 valid votes was cast and the turnout was put at about $58 \%$ of the 61567036 registered voters. Nigerians had reasons to participate enthusiastically in the voting process - above all else, the 2007 elections were watershed elections - it was the first time a democratically elected civilian administration would successfully complete the constitutionally prescribed two terms in office, conduct elections and hand over to another civilian administration.

In a related vein, since this was the third election in the series, many more Nigerians should have been acquainted with the electoral process. However, the 'do-or-die' nature of the elections and the fact that the results were controversial and contested, coupled with the discrepancies and distortions associated with the voters' register and the undue militarisation of the process, are sufficient reason to doubt the validity of the ascribed turnout.

From the data above it is evident that voter turnout in Nigerian elections has generally been poor. While there is a specific explanation for the level of turnout recorded in each election, as shown in the preceding analyses, a common thread can be found in the nature of the democratisation process, including the inherent 
weaknesses of its institutional foundation, especially the electoral law (Aiyede 2007), the election management body, namely the Independent National Electoral Commission (INEC) (Agbaje \& Adejumobi 2006; Omotola 2010a), political parties and associated problems such as electoral corruption and violence, as well as poor levels of political education and mobilisation (Omotola 2010b).

\section{VOTER TURNOUT IN THE 2011 ELECTIONS}

April 2011 was a critical month for Nigeria's democratisation process. During that month Nigerians went to the polls for both executive and parliamentary elections at both federal and state levels. There is now an emerging body of knowledge about the elections, most of which tends to eulogise them as the best administered of those held under the Fourth Republic (Egwu 2011; Gberie 2011; Akhaine 2011).

Egwu (2011) was particularly celebratory, declaring that the election signified 'a farewell to electoral authoritarianism' in Nigeria. While the focus here is not to debate the validity or otherwise of such claims, and granted that the elections had the trappings of a marked improvement on previous ones, especially if one relies for one's information on the reports of local and international monitors, it is important to note that they were far from meeting accepted democratic standards. ${ }^{1}$ One of the main reasons for this is the low level of voter turnout, especially its spatial dimension. Available data, as shown in Table 2, reveal that the turnout hovers around $50 \%$.

Specifically, of the 73528040 registered voters, 39469484 (53.7\%) voted in the presidential election on 16 April. ${ }^{2}$

Table 2

Turnout for the 2011 Elections

\begin{tabular}{|l|l|l|l|}
\hline Elections & Registered voters & Turnout & Percentage \\
\hline Presidential & 73528040 & 39469484 & 53.70 \\
\hline Senate & 73528040 & $\mathrm{Na}$ & About 50 \\
\hline House of Representatives & 73528040 & $\mathrm{Na}$ & About 50 \\
\hline
\end{tabular}

1 One of these authors, J Shola Omotola, holds a dissenting view and is currently putting his thoughts together in a piece tentatively titled 'Nigeria's 2011 Elections: A Dissenting View', being prepared for African Affairs.

2 Turnout data for the Senate and House of Representative elections are not easy to compute for a number of reasons, most notably the manner in which INEC released the results on a senatorial and constituency basis without showing the overall total of votes cast. 
As noted above, turnout is the most important indicator of popular participation in an election and, by extension, of the legitimacy of government. While an average level of participation of $53.7 \%$ may not necessarily be poor, especially in the light of a global recession in voter turnout or, rather, an increase in voter apathy, one would have expected a higher turnout in the 2011 election for a number of reasons.

Firstly, following the discredited elections of 2007 a process of electoral reform was initiated with the setting up of an electoral reform committee headed by retired Justice Muhammed Uwais, which climaxed with the appointment as INEC chairman of Professor Attahiru Jega, a widely acclaimed political scientist with a reputation for great integrity. There were other independence-enhancing outcomes, notably the granting of financial autonomy to INEC and the amendment of the electoral law and relevant constitutional provisions to give effect to the reform measures (see Omotola 2011a). These measures, among others, were expected to restore public confidence in electoral institutions and processes. Consequently, popular enthusiasm and participation in the process should have surged.

Secondly, the 2011 elections were heavily influenced by social media, particularly mobile phones, Facebook and Twitter. Virtually all the main presidential aspirants exploited these new media for political marketing and mobilisation. Even legislative candidates at the federal and state levels created and serviced online avenues to market their programmes and mobilise potential voters.

In addition, the dominant political parties, among them the People's Democratic Party (PDP), the Action Congress of Nigeria (ACN), the Congress for Progressive Change (CPC) and the All Nigeria Peoples Party (ANPP) waged elaborate and well-funded political campaigns. Goodluck Jonathan's presidential campaign was notable for its 'Neighbour-to-Neighbour' (N2N) strategy, through which he reached out to most, if not all, registered voters. To sum up, the level of mobilisation was unprecedented.

This, coupled with the efforts of civil society organisations through voter education and mobilisation, should have resulted in a higher turnout. But, for various reasons, this was not to be. One is that prior to the elections the political atmosphere was tense because of President Yar'Adua's health crisis, the undue politicisation of his absence from duty and the prolonged refusal to make Goodluck Jonathan acting president, as is constitutionally required.

The eventual swearing in of Jonathan, following the death of Yar'Adua, and Jonathan's decision to contest the presidential election, set the tone of that election (Omotola 2011b). Essentially, it animated, more than ever before, the debate about zoning and about rotating the presidency between the North and the South, which had become of prime importance within the PDP since 1999 (Kendhammer 2010). 
The inability of Alhaji Atiku Abubakar, former vice-president under Obasanjo, and the ACN's presidential candidate in the 2007 election, to clinch the PDP nomination for the North was interpreted by the North as a kind of betrayal and only served to complicate matters. The attendant deep polarisation along ethno-regional lines, apart from generating its own tensions, including low voter turnout, also underlined the spatial pattern of voting. Worse still, the elections were characterised by excessive violence before, during and after, a development that does not augur well for voter turnout. As Amnesty International (2011) reported, hundreds of people were killed in 'politically motivated, communal and sectarian violence across Nigeria ahead of presidential and parliamentary polls'.

But the turnout was not uniformly low - an unprecedentedly high number of people voted in the South East and the South-South. The two leading opposition parties, the $\mathrm{ACN}$ and the $\mathrm{CPC}$, for example, complained bitterly about what they called magic numbers. According to the $\mathrm{ACN}{ }^{3}$

... An analysis of the results put out by INEC itself has shown a troubling pattern of clear manipulation. Everywhere the PDP perceived it was strong, it came out with incredibly high numbers of voters in its favour. Conversely, anywhere the opposition was perceived to be strong, the opposition`s margin of victory was unreasonably low.

Osun Defender, 21 April 2011; Daily Trust 2011

In trying to substantiate the allegation, the $\mathrm{ACN}$ gave the following examples: ${ }^{4}$

In the South-South and South-East, where President Jonathan is believed to have strong support, the average turnout was $67 \%$ each of registered voters, compared to $32 \%$ for the South-West where he is believed to have a strong opposition. In the North-West and NorthEast, which is considered a bastion of opposition in the north, the average turnout of registered voters was $54 \%$.

And whereas high voter turnout was recorded in states perceived to be sympathetic to President Jonathan in the different geopolitical zones (Bayelsa in South-South 85\%, Imo in South-East 84\%, and Plateau in North-Central 62\%), the opposite was the case for areas where the opposition, was believed to be strong. Even in

3 These allegations constitute the bases of petitions by the CPC against Jonathan's presidential victory, which are yet to be finalised by the electoral tribunal.

4 The same source and data have been used in a previous work (see Omotola 2011a). See also Gberie 2011. 
Katsina, Buhari's hometown, the turnout was a paltry 52\%! Ditto for Kano (53\%); Sokoto (40\%) and Zamfara (51\%).

It is also instructive that even though Edo state is in the South-South, the turnout was only $37 \%$, apparently because the state was not believed - by the figure cooks - to be sympathetic to President Jonathan, being controlled by the ACN. The turnout figures for the South-West are also revealing: Lagos (31.8\%); Ogun (28\%); Osun (39\%) and Oyo (33\%).

Also, while the margin of victory for the PDP in the South-South is $98 \%$ and for the South-East 98.9\%, the highest margin of victory for the CPC in the NorthWest, where Buhari comes from, is $55.8 \%$.

This pattern of voting speaks volumes, not only about the probable inflation of voter turnout, but also its geographical lopsidedness. If the candidacy of Jonathan, an Ijaw man from the oil-rich Niger Delta, could be taken as a plausible reason for the massive turnout in the South-South it can be argued that the presence of three presidential candidates from the North, namely General Muhammadu Buhari of the CPC, Malllam Nuhu Ribadu of the ACN and Mallam Ibrahim Shekarau of the ANPP, should have produced a similar level of turnout in the region. This did not happen.

The high turnout in the South East, which has none of the most viable presidential aspirants, measured largely by the strength of their political platforms, appears much more difficult to explain. It is, however, possible to argue about the positive impact Jonathan's bold claim to an Igbo name -Azikiwe - may have had on the psyche of the average Igbo voter. As appealing as these factors may sound, coupled with the fact that geopolitical considerations have been known to influence voting behaviour in Nigeria (Olaniyi 2004), they are not an adequate explanation of the disproportionate spatial pattern of turnout.

Be that as it may, it is useful to underscore two important points that could have contributed to the skewed geopolitical pattern of turnout. The first was the crisis that rocked the presidency in the wake of the Yar'Adua health crisis. The way Jonathan was treated by the 'cabal', especially the refusal to make him acting president, thereby creating a presidential vacuum for some time, generated a reasonable level of public sympathy and support for him.

Secondly, and closely related to this, is the fact that as an Ijaw man from Nigeria's oil enclave, the Niger Delta, a region that has hitherto been on the margins of politics in the country, it is only natural that he would receive support from the entire region.

It is not clear how the politics of issues, that is, considerations based on salient issues raised by aspirants / parties, for example, relating to the economy, affected voter turnout generally and geopolitically. While Jonathan predicated his campaign on 'transformation' and the experiences of his deprived childhood 
and upbringing, his message was national and not restricted to the South-South and South East. Nevertheless, it may be argued that the two regions were more open than others to the transformational message because of the developmental challenges confronting them and therefore they would benefit most from the transformation agenda. If so, the expectation of an assured future for the deprived should have resonated better in the North, where the level of child deprivation would appear to be higher. This was not the case.

Despite notable reservations expressed in election petitions and suits, the sanctity of the 2011 elections results has finally been established with the determination of the presidential election cases by the Supreme Court. The import of this is that the election results, including the spatial distribution, were, after all, correct. Yet it is instructive to note that in most cases the outcome of election petitions was largely determined by technicalities rather than available evidence. This was the case with the contested presidential election. ${ }^{5}$

\section{CONCLUSION}

This article has engaged with the important issue of turnout in Nigerian elections as a cardinal pillar of political participation. The analysis reveals that voter turnout since 1999 has generally been low, hovering around 50\% or slightly below. The reasons for this tend to vary from one election to another. However, there are common factors that cut across the various elections. These include ethno-regional considerations, the level of trust in electoral institutions and processes at any point in time, the disposition of the government (ruling party) towards free and fair elections, campaign issues, the level of political education and mobilisation, voting experience, and so on.

With specific reference to the 2011 elections, however, while these factors generally apply, several other important elements played crucial roles. Among these were the growing deployment and influence of the social media; the electoral reform process, which boosted public trust in electoral institutions and processes, and President Jonathan's oft-repeated assurances to the local and international community that he would not interfere in the electoral process. The turnout would have been higher but for the level of violence that preceded the elections, as well as that on election days.

There were also unprecedented, significant spatial variations in the level of turnout in the 2011 presidential election, which were not replicated in other elections. As shown in the analysis, turnouts were higher in the South-South

5 For the Supreme Court judgement, see Ndujihe, Nnochiri \& Akinrefon 2011 and for reactions, see Leadership, 28 December 2011. Available at: allafrica.com/stories/201112290166.html 
and the South East than in other geopolitical zones of the country, leading to unsubstantiated allegations that the results were deliberately falsified in favour of the incumbent, President Jonathan. The spatial variations in voter turnout have been explained in terms of various factors, including the politics of succession in the wake of Yar'Adua's health crisis and eventual death, the phenomenon of Jonathanism which grew out of popular sympathy over the shoddy treatment meted out to him while the crisis lasted, and Jonathan's background as an Ijaw man from the Niger delta, which had never had the opportunity to taste the presidency, despite being the region that lays the golden egg for Nigeria.

The 2011 elections showed that there is room for improvement in voter turnout. To attain this, certain steps are desirable.

Firstly, there is a need to build on the gains of the electoral reform process, thereby improving the level of public trust in electoral institutions and processes. This requires revisiting the Uwais report to restore salient recommendations that have thus far been jettisoned. A most notable aspect here is the unbundling of INEC to create specialised agencies for specialised activities, such as special election courts to try election offences.

Secondly, it is possible to make voting a condition for accessing some benefits. After all, rights are, ordinarily, corollaries of duties. Some state governments in the South West experimented during the 2011 elections, making voting a condition for remuneration, and it worked.

Thirdly, the importance of political education and mobilisation cannot be overemphasised. Political parties and civil society organisations should take advantage of the electoral reform process at all stages to facilitate a voter-friendly environment. These bodies, together with the election management body, should embark on a sustainable process of political education and mobilisation of the populace. Finally, given the effect of the social/new media on the 2011 elections, it is important to consolidate the gains by promoting an enabling environment for the expansion of their applicability. Making information and communication technology part of the academic curriculum at all levels of education could be the starting point. Then the question of affordability is also crucial, which boils down to good governance of the economy at all levels to enhance the standard of living for Nigeria's people. 


\section{- REFERENCES}

Adebayo, P F \& J S Omotola. 2007. 'Public Perceptions of Nigeria's 2007 General Elections'. Journal of African Elections 6(2).

Agbaje, A \& S Adejumobi. 2006. 'Do Votes Count? The Travail of Electoral Politics in Nigeria'. Africa Development XXXI (3).

Aiyede, E R. 2007. 'Electoral Laws and the 2007 General Elections in Nigeria'. Journal of African Elections 6(2).

Ajayi, K. 2006. 'The Security Forces, Electoral Conduct and the 2003 General Elections'. Journal of Social Sciences 13(1).

Odion-Akhaine, S. 2009. 'Liberal Democracy, the Democratic Method and the Nigerian 2007 Elections'. Journal of Asian and African Studies 44(6).

Akhaine, S O. 2011. 'Nigeria's 2011 elections: The “crippled giant" learns to walk?'. African Affairs 110(441).

Altman, D \& A Perez-Linan. 2002. 'Assessing the Quality of Democracy: Freedom, Competitiveness and Participation in Eighteen Latin American Countries'. Democratization 9(2).

Amnesty International. 2011. Loss of Life, Insecurity and Impunity in the Run-up to Nigeria's Elections, March.

Babarinsa, D. 2002. The House of War. Ibadan: Spectrum Publishers.

Berg-Schlosser, D \& N Kersting. 2003. 'Poverty and Democracy: A Contradiction?'. In D Berg-Schlosser \& N Kersting (eds). Poverty and Democracy: Self-Help and Political Participation in Third World Cities. London: Zed Books.

Blais, A \& R K Carty. 1990. 'Does Proportional Representation Foster Voter Turnout?' European Journal of Political Research 18.

Blais, A \& A Dobrzynska. 1998.'Turnout in electoral democracies'. European Journal of Political Research 33.

Booth, J A \& M A Seligson. 1978. 'Images of Political Participation in Latin America'. In J A Booth and M A Seligson (eds). Citizen and State: Political Participation in Latin America Vol 1. New York and London: Holmes and Meier Publishers.

Bratton, M. 1998. 'Second Elections in Africa'. Journal of Democracy 7(1).

Bratton, M. 1999. 'Political Participation in a New Democracy. Institutional Considerations from Zambia', Comparative Political Studies, 32(5).

Budge, I \& D Farlie. 1977. Voting and Parry Competition: A Theoretical Critique and Synthesis Applied to Surveys from Ten Democracies. London, New York, Sydney and Toronto: John Wiley and Sons.

Conge, P J. 1988. 'Review Article: The Concept of Political Participation: Toward a Definition'. Comparative Politics 20(2), January. 
Cornwall, A. 2002. Making Spaces, Changing Places: Situating Participation in Development. Institute of Development Studies (IDS) Working Paper No 170. Brighton: IDS.

Daily Trust. Available at: www.dailytrust.com/dailytrust/index.php?option=com content\&view=article\&id=17646:presidential-poll-most-systematicallyrigged-acn-says\&catid $=2$ :lead-stories\&Itemid $=8$.

Dalton, R. 2006. 'Citizenship Norms and Political Participation in America: The Good News Is ... the Bad News Is Wrong'. Centre for Democracy and Civil Society Occasional Paper 2006-01, Georgetown University, Washington, DC.

Darmofal, D. 2006. 'The political geography of macro-level turnout in American political development'. Political Geography 25.

Diamond, L, A Kirk-Green \& A Oyediran (eds). 1997. Transition Without End: Nigerian Politics and Civil Society under Babangida. Ibadan: Vantage.

Diamond, L. 2008. The Spirit of Democracy: The Struggle to Build a Free Society Throughout the World. New York: Times Books.

Driskell, R, E Embry \& L Lyon. 2008. 'Faith and Politics: The Influence of Religious Beliefs on Political Participation'. Social Science Quarterly 82(9).

Dudley, B J. 1982. An Introduction to Nigerian Government and Politics. London: Macmillan.

Egwu, S. 2011. 'Farewell to Electoral Authoritarianism?: Pathways to Democratic Consolidation in Nigeria'. NPSA presidential address delivered at Usumanu Dan Fodio University, Sokoto, 21 June 2011.

Franklin, M N. 2004. Voter Turnout and the Dynamics of Electoral Competition in Established Democracies Since 1945. Cambridge: Cambridge University Press.

Freitag, M. 2010. 'Structure versus Culture: A Comparative Study of the Influence of Political Institutions and Cultural Modernization Factors on Voter Turnout in Swiss Sub-national Parliamentary Elections'. International Political Science Review 31(4).

Gberie, L. 2011. The 2011 Elections in Nigeria: A New Dawn? Institute for Security Studies Situation Report, 13 March.

Gimpel, J G \& J E Schuknecht. 2003. 'Political Participation and the Accessibility of the Ballot Box'. Political Geography 22.

Gray, M \& M Caul. 2000. 'Declining Voter Turnout in Advanced Industrial Democracies, 1950 to 1997. Comparative Political Studies 33(2).

Huntington, S P \& J M Nelson. 1976. No Easy Choice: Political Participation in Developing Countries. Cambridge, Mass: Harvard University Press.

Joseph, R. 1987. Democracy and Prebendal Politics in Nigeria: The Fall of the Second Republic. Cambridge: Cambridge University Press. 
Journal of African Elections. 2007. Special Issue on the 2007 Nigerian General Elections 6(2).

Kaase, M \& A Marsh. 1979. 'Political Action: A Theoretical Perspective'. In H Barness \& M Kaase (eds). Political Action: Mass Participation in Five Western Democracies. Beverly Hills: Sage Publications.

Kendhammer, B. 2010. 'Talking ethnic but hearing multi-ethnic: The People's Democratic Party (PDP) in Nigeria and durable multi-ethnic parties in the midst of violence'. Commonwealth and ComparativePolitics 48(1).

Kuenzi, M \& G MS Lambright. 2007. 'Voter Turnout in Africa's Multiparty Regimes'. Comparative Political Studies 40(6).

Kurfi, A. 1983.The Nigerian General Elections 1959 and 1979 and the Aftermaths. Lagos and Ibadan: Macmillan Nigerian Publishers Ltd.

Ladner, A\& H Milner. 1999. 'Do Voters Turn Out More Under Proportional Than Majoritarian Systems? The Evidence from Swiss Communal Elections'. Electoral Studies 18.

Leadership. 2011. 'Nigeria: Presidential Election - NBA, Lawyers React to Supreme Court Verdict', 28 December. Available at: allafrica.com/stories/ 201112290166. html

Lijphart, A. 1997. 'Unequal participation: democracy's unresolved dilemma. American Political Science Review 91(1).

Lijphart, A. 2006. Democracy and Elections in Africa. Baltimore, MD: Johns Hopkins University Press.

Lijphart, A. 2009a. 'Introduction'. In S I Lindberg(ed). Democratization by Elections: A New Mode of Transition?. Baltimore, MD: Johns Hopkins University Press.

Lijphart, A. 2009b. 'The Power of Elections Revisited'. In S I Lindberg (ed). Democratization by Elections: A New Mode of Transition? Baltimore, MD: Johns Hopkins University Press.

Lijphart, A. 2009c. 'A Theory of Elections as a Mode of Transition'. In S I Lindberg (ed). Democratization by Elections: A New Mode of Transition? Baltimore, MD: Johns Hopkins University Press.

Lindberg, S I. 2004. 'The Democratic Qualities of Competitive Elections: Participation, Competition and Legitimacy in Africa'. Commonwealth and Comparative Politics 42(1).

Meredith, M. 2009. 'Persistence in Political Participation'. Quarterly Journal of Political Science 4.

Milner, H \& R Ladner. 2006. 'Can PR Voting Serve as a Shelter Against Declining Turnout?: Evidence from Swiss Municipal Elections'. International Political Science Review 27(1).

Ndujihe, C, I Inochiri \& D Akinrefon. 2011. 'Nigeria: Supreme Court Confirmation of President - Accept Defeat, Jonathan Tells Buhari'. Vanguard, 29 December. 
Nelson, J M. 1976. No Easy Choice: Political Participation in the Developing Countries. Cambridge, Mass: Harvard University Press.

Nelson, J M. 1979. Access to Power: Politics and Urban Poor in Developing Nations. Princeton, NJ: Princeton University Press.

Nwosu, H. 2008. Laying the Foundation for Nigeria's Democracy: My Account of June 12, 1993 Presidential Election and its Annulment. Lagos: Macmillan.

Odion-Akhaine, S. 2009. 'Liberal Democracy, the Democratic Method and the Nigerian 2007 Elections'. Journal of Asian and African Studies 44(6).

Ojiako, O. 1981. Nigeria Yesterday, Today and ...? Onitsha: Africana Educational Publishers Nigeria Ltd.

Olaniyi, J O. 2004. 'A Geopolitical Perspective of the Voting Behaviour of the Nigerian Electorate'. Political Science Review 3(1-2).

Olaniyi, J O. 2008. 'The Phenomenon of Low Voter Turnout in Nigerian Elections'. In H A Saliu, H I Jimoh, N Yusuf \& E O Ojo (eds). Perspectives on NationBuilding and Development in Nigeria: Political and Legal Issues. Lagos: Concept Publications.

Omoruyi, O. 1993.The Annulment of the 12 June Election: The Betrayal of the Democratic Rights of Nigerians. Lagos: NewLink.

Omotola, J S. 2004. 'The 2003 Nigerian Second Elections: Some Comments', Political Science Review, 3(1-2).

Omotola, J S. 2006. 'The Limits of Election Monitoring: The 2003 Nigerian General Elections'. Representation: A Journal of Representative Democracy 42(2).

Omotola, J S. 2007. 'Godfathers and the 2007 Nigerian General Elections'. Journal of African Elections 6(2).

Omotola, J S. 2008. 'From Importer to Exporter: The Changing Role of Nigeria in Promoting Democratic Values in Africa'. In J Pretorius (ed). African Politics: Beyond the Third Wave of Democratisation. Cape Town: Juta Academic Press.

Omotola, J S. 2009. 'Garrison Democracy in Nigeria: The 2007 General Elections and the Prospects of Democratic Consolidation'. Commonwealth and Comparative Politics 47(2).

Omotola, J S. 2010a. 'Elections and Democratic Transitions in Nigeria under the Fourth Republic'. African Affairs 109(437).

Omotola, J S. 2010b. 'Political Parties and the Quest for Political Stability in Nigeria'. Taiwan Journal of Democracy 6(2).

Omotola, J S. 2011a. 'Electoral Reform and the Prospects of Democratic Consolidation in Nigeria'. Journal of African Elections 10(1).

Omotola, JS. 2011b. 'A Cabalised Regime: Neopatrimonialism, President Yar'Adua's Health Crisis and Nigeria's Democracy'. CEU Political Science Journal 6(2).

Osaghae, E E. 1998. Nigeria Since Independence: Crippled Giant. London: C Hurst and Co. 
Osun Defender. 2011. '2011 Presidential Poll Most Systematically Rigged', 21 April. Available at: $w w w . o s u n d e f e n d e r . o r g / ? p=15421$

Pateman, C.1970. Participation and Democratic Theory. NewYork: Cambridge University Press.

Plutzer, E. 2002. 'Becoming a Habitual Voter: Inertia, Resources and Growth in Young Adulthood'. American Political Science Review 96.

Post, K W J. 1963. The Nigerian Federal Elections, 1959. London: Oxford University Press.

Schaffer, F C. 2002. 'Might Cleaning Up Elections Keep People Away from the Polls? Historical and Comparative Perspectives'. International Political Science Review 23(1).

Squire, P, R E Wolfinger \& D P Glass. 1987. 'Residential Mobility and Voter Turnout'. American Political Science Review 81.

Stein, R, C Owen \& J Leighley. 2002. 'Electoral Reform, Party Mobilization and Voter Turnout'. Available at: www.nyu.edu/gsas/dept/ politics/seminars/ leighley.pdf

Suberu, R T. 2007. 'Nigeria's Muddled Elections'. Journal of Democracy 18(3).

Verba, S \& N H Nie. 1972. Participation in America: Political Democracy and Social Equality. New York: Harper and Row.

Young, I M. 2000. Inclusion and Democracy. Oxford: Oxford University Press. 